\title{
Kurang Energi Kronis pada Wanita Usia Subur di Wilayah Kecamatan Limboto, Kabupaten Gorontalo
}

\section{Chronic Energy Malnutrition in Women Reproductive Age Limboto District, Gorontalo Regency}

\author{
Yeni Paramata* dan Marselia Sandalayuk \\ Program Studi Ilmu Kesehatan Masyarakat, Fakultas Kesehatan Masyarakat \\ Universitas Gorontalo \\ *email : yeniparamata20@gmail.com
}

\begin{abstract}
Chronic Energy Malnutrition (CEM) is a situation where young women/women experience nutritional deficiencies (calories and protein) that last long or chronic. In 2013 based on basic health research data the prevalence of CEM in Gorontalo district was $12.5 \%$ in women aged $15-49$ years who were pregnant and $15.1 \%$ in women aged 15-49 years who were not pregnant. To prevent the risk of CEM in pregnant women before pregnancy, women of childbearing age must have good nutrition, for example with the Upper Arm Circumference not less than $23.5 \mathrm{~cm}$. Based on the above problems, this study aims to describe the incidence of chronic energy malnutrition in women of reproductive age (15-49 years) in Limboto subdistrict, Gorontalo Regency. This research was carried out in the Tilihuwa village, with a sample of 162 fertile women aged 15-49 years who were selected by accidental sampling. This research was a descriptive study with a cross sectional approach. The results of this study found that the highest incidence of CEM in the group of women aged 15-24 years was 13 people (81.3\%), the level of education was only elementary school graduates 7 people (43.8\%), the status of employment as a housewife was 10 people (62.5\%) and all who suffer from non-pregnant CEM was 16 people (100\%). The conclusion was the largest of CEM in the age group 1524 years (81.3\%), only completed primary school education (43.8\%), housewife $(62.5 \%)$ and not pregnant (100\%). The suggestion is there important to increase access the information on women reproductive age with low education levels and improve nutrition in adolescence and early adult group.
\end{abstract}

Keywords; chronic energy malnutrition, women reproductive age, education, employement, pregnancy status

\begin{abstract}
Abstrak
Kekurangan Energi Kronik (KEK) adalah keadaan dimana remaja putri/wanita mengalami kekurangan gizi (kalori dan protein) yang berlangsung lama atau menahun. Pada tahun 2013 berdasarkan data riset kesehatan dasar prevalensi KEK di kabupaten Gorontalo sebesar 12,5\% pada wanita usia 15-49 tahun yang sedang hamil dan $15,1 \%$ pada wanita usia 15-49 tahun yang tidak hamil. Untuk mencegah risiko KEK pada ibu hamil sebelum kehamilan, wanita usia subur (WUS) sudah harus mempunyai gizi yang baik, misalnya dengan LILA tidak kurang dari $23,5 \mathrm{~cm}$. Berdasarkan permasalahan diatas penelitian ini bertujuan untuk mengambarkan kejadian kurang energi kronik pada wanita usia subur (15-49 tahun) di kecamatan Limboto Kabupaten Gorontalo. Penelitian ini dilaksanakan di kelurahan Tilihuwa, dengan jumlah sampel sebanyak 162 WUS usia 15-49 tahun yang dipilih secara accidental sampling. Penelitian ini merupakan studi deskriptif dengan pendekatan cross sectional. Hasil penelitian
\end{abstract}


ini didapatkan bahwa kejadian KEK terbanyak pada kelompok wanita usia 1524 tahun yaitu 13 orang $(81,3 \%)$, tingkat pendidikan hanya tamatan SD yaitu 7 orang $(43,8 \%)$, status pekerjaan sebagai Ibu Rumah Tangga saja yaitu 10 orang $(62,5 \%)$ dan seluruhnya yang menderita KEK tidak sedang hamil yaitu 16 orang $(100 \%)$. Kesimpulan dari penelitian ini adalah KEK terbanyak pada kelompok usia 15-24 tahun (81,3\%), pendidikan hanya tamatan SD $(43,8 \%)$, Ibu Rumah Tangga $(62,5 \%)$ dan tidak sedang hamil (100\%). Disarankan perlu peningkatan akses informasi pada WUS dengan tingkat pendidikan rendah dan perbaikan gizi pada kelompok remaja dan dewasa awal.

Kata kunci; kurang energi kronis, wanita usia subur, pendidikan, pekerjaan, status kehamilan

\section{PENDAHULUAN}

Kekurangan Energi Kronik (KEK) adalah salah satu keadaan malnutrisi. Dimana keadaan ibu menderita kekurangan makanan yang berlangsung menahun (kronik) yang mengakibatkan timbulnya gangguan kesehatan pada ibu secara relatif atau absolut satu atau lebih zat gizi (Helena, 2013).

Kekurangan energi kronis pada WUS sedang menjadi fokus pemerintah dan tenaga kesehatan sekarang ini. Hal ini dikarenakan seorang WUS yang KEK memiliki risiko tinggi untuk melahirkan anak yang akan menderita KEK dikemudian hari. Selain itu, kekurangan gizi menimbulkan masalah kesehatan (morbiditas, mortalitas dan disabilitas), juga menurunkan kualitas Sumber Daya Manusia (SDM) suatu bangsa. Dalam skala yang lebih luas, kekurangan gizi dapat menjadi ancaman bagi ketahanan dan kelangsungan hidup suatu bangsa (Mboi, 2013).

Faktor-faktor yang mempengaruhi KEK pada WUS terbagi menjadi dua, yaitu faktor internal dan eksternal. Faktor internal (individu/keluarga) yaitu genetik, obstetrik, seks. Sedangkan faktor eksternal adalah gizi, obat-obatan, lingkungan dan penyakit (Supariasa dkk, 2012).

Hasil Riset Kesehatan Dasar (Riskesdas) 2013 didapatkan angka prevalensi risiko KEK di Indonesia adalah 31,3\% pada wanita hamil dan 20,8\% pada WUS. Di Provinsi Gorontalo sendiri 22,7\% pada wanita hamil dan $26,8 \%$ pada WUS. Sedangkan di Kabupaten Gorontalo sendiri risiko KEK cukup tinggi, yaitu $12,5 \%$ pada wanita hamil dan $15,1 \%$ pada WUS (Kemenkes, 2013). Kecamatan Limboto khususnya Kelurahan Tilihuwa merupakan desa binaan dari Fakultas Kesehatan Masyarakat Universitas Gorontalo, sehingga beberapa penelitian dan pengabdian diarahkan ke lokasi tersebut.

Berdasarkan permasalahan diatas penelitian ini bertujuan untuk mengetahui gambaran karakteristik Kurang Energi Kronik pada Wanita Usia Subur (15-49 tahun) di wilayah kecamatan Limboto Kabupaten Gorontalo.

\section{METODE}

Penelitian ini menggunakan metode survey dengan desain deskriptif dan pendekatan cross sectional yang bertujuan untuk mengetahui gambaran karakteristik dan Kurang Energi Kronik pada Wanita Usia Subur (15-49 tahun) di wilayah Kecamatan Limboto Kabupaten Gorontalo. Penelitian ini dilakukan selama 2 bulan di kecamatan Limboto Kabupaten Gorontalo, khususnya kelurahan Tilihuwa yang menjadi lokasi binaan Fakultas Kesehatan Masyarakat. Populasi WUS berjumlah 826 orang dan sampel sebanyak 177 orang. Penarikan sampel dilakukan dengan teknik simple random sampling dimana subyek yang dipilih diambil secara acak tanpa memperhatikan tingkatan yang ada dalam populasi.

Data diperoleh dengan pengisian formulir identitas responden oleh peneliti dengan wawancara kepada WUS. Data Lingkar Lengan Atas diukur dengan pita 
Lila dengan kapasitas $33 \mathrm{~cm}$ dengan tingkat ketelitian 0,1 cm. Pengukuran LILA dimulai dari menentukan titik diantara acromion dan prosessus olecranon dalam keadaan berdiri atau duduk pada lengan kiri, kemudian diukur lingkar pada titik tersebut. Data dianalisis secara univariat dan bivariat yang dilakukan untuk mendapatkan gambaran umum dengan cara mendeskripsikan tiap-tiap variabel yang digunakan dalam penelitian yaitu dengan melihat gambaran distribusi frekuensi dalam bentuk tabel.

\section{HASIL DAN PEMBAHASAN Analisis Karakteristik Subjek Penelitian}

Tabel 1. Gambaran Karakteristik Wanita Usia Subur berdasarkan Kelompok Umur, Tingkat Pendidikan, Pekerjaan dan Status Kehamilan

\begin{tabular}{lcc}
\hline \multirow{2}{*}{ Karakteristik WUS } & \multicolumn{2}{c}{ Jumlah } \\
\cline { 2 - 3 } & $\mathrm{N}$ & $\%$ \\
\hline Umur (tahun) & 64 & 36,2 \\
$15-24$ & 52 & 29,3 \\
$25-34$ & 61 & 34,5 \\
$35-44$ & & \\
Pendidikan & 1 & 0,5 \\
Tidak Sekolah & 79 & 44,7 \\
SD & 62 & 35,0 \\
SMP & 32 & 18,1 \\
SMA & 3 & 1,7 \\
Perguruan Tinggi & & \\
Pekerjaan & 7 & 3,9 \\
Bekerja & 170 & 96,1 \\
Tidak Bekerja & & \\
Status Kehamilan & 5 & 2,8 \\
Hamil Total & 172 & 97,2 \\
Tidak Hamil & 177 & 100 \\
\hline \multicolumn{2}{c}{ Tal } & \\
\hline
\end{tabular}

Pada Tabel 1 menunjukkan dari total 177 responden yang diteliti, menunjukan bahwa sampel yang tertinggi pada kelompok umur 15-24 tahun yaitu sebanyak 64 responden $(36,2 \%)$ dan terendah pada kelompok umur 25-34 tahun sebanyak 52 responden $(29,3 \%)$, tingkat pendidikan tertinggi hanya tamatan SD sebanyak 79 responden $(44,7 \%)$ dan terendah yaitu tidak sekolah sebanyak 1 responden $(0,5 \%)$, status dengan tidak bekerja sebanyak 170 responden $(96,1 \%)$ dan yang terendah yaitu pada kategori bekerja sebanyak 7 responden $(3,9 \%)$ dengan status tidak hamil sebanyak 172 responden $(97,2 \%)$ dan hamil 5 responden $(2,8 \%)$.

\section{Analisis Kejadian KEK pada WUS}

Berdasarkan Tabel 2 didapatkan bahwa dari total 177 responden dengan kategori KEK terbanyak pada kelompok umur 15 - 24 tahun yaitu 13 orang $(81,3 \%)$, dilihat dari tingkat pendidikan kategori KEK terbanyak pada pendidikan SD yaitu 7 orang (43,8\%). Berdasarkan status pekerjaan kategori KEK terbanyak pada Ibu Rumah Tangga yaitu 10 orang $(62,5 \%)$ dan berdasarkan status kehamilan dengan kategori KEK keseluruhan terdapat pada wanita usia subur yang sedang tidak hamil yaitu 16 orang $(100 \%)$.

Tabel 2. Kejadian KEK pada Wanita Usia Subur berdasarkan Kelompok Umur, Tingkat Pendidikan, Pekerjaan dan Status Kehamilan 


\begin{tabular}{|c|c|c|c|c|c|c|}
\hline \multirow{3}{*}{ Variabel } & \multicolumn{4}{|c|}{ Kejadian KEK } & \multicolumn{2}{|c|}{ Total } \\
\hline & \multicolumn{2}{|c|}{ KEK } & \multicolumn{2}{|c|}{ Tidak KEK } & \multirow[b]{2}{*}{$\mathrm{n}$} & \multirow[b]{2}{*}{$\%$} \\
\hline & $\mathrm{N}$ & $\%$ & $\mathrm{n}$ & $\%$ & & \\
\hline \multicolumn{7}{|c|}{ Kelompok Umur (Tahun) } \\
\hline $15-24$ & 13 & 81,3 & 51 & 31,7 & 64 & 36,2 \\
\hline $25-34$ & 3 & 18,7 & 59 & 36,6 & 52 & 29,3 \\
\hline $35-44$ & 0 & 0 & 51 & 31,7 & 61 & 34,5 \\
\hline \multicolumn{7}{|l|}{ Tingkat Pendidikan } \\
\hline Tidak Sekolah & 0 & 0 & 1 & 0,6 & 1 & 0,5 \\
\hline SD & 7 & 43,8 & 72 & 44,7 & 79 & 44,7 \\
\hline SMP & 4 & 25 & 58 & 36,0 & 62 & 35,0 \\
\hline SMA/MA & 5 & 31,2 & 27 & 16,8 & 32 & 18,1 \\
\hline Perguruan Tinggi & 0 & 0 & 3 & 1,9 & 3 & 1,7 \\
\hline \multicolumn{7}{|l|}{ Status Pekerjaan } \\
\hline IRT & 10 & 62,5 & 133 & 82,6 & 143 & 80,7 \\
\hline Siswa/Mahasiswa & 6 & 37,5 & 21 & 13,0 & 27 & 15,3 \\
\hline Petani & 0 & 0 & 7 & 4,4 & 7 & 4,0 \\
\hline \multicolumn{7}{|l|}{ Status Kehamilan } \\
\hline Hamil & 0 & 0 & 5 & 3,1 & 5 & 2,8 \\
\hline Tidak Hamil & 16 & 100 & 156 & 96,9 & 172 & 97,2 \\
\hline
\end{tabular}

Hasil penelitian menunjukan bahwa dari total 177 responden WUS dengan kategori KEK terbanyak pada kelompok umur 15 - 24 tahun yaitu 13 orang $(81,3 \%)$. Terjadi peningkatan kebutuhan zat gizi pada remaja putri berkaitan dengan percepatan pertumbuhan yang dialaminya, dimana zat gizi yang diserap tubuh digunakan untuk meningkatkan berat badan dan tinggi badan, disertai dengan meningkatnya jumlah ukuran jaringan sel tubuh untuk mencapai pertumbuhan yang optimal (Waryono, 2009). Banyak remaja yang bertubuh sangat kurus akibat kekurangan gizi atau sering disebut gizi buruk, jika sudah terlalu lama maka akan terjadi kurang energi kronik (KEK) (Wuryani, 2007).

Hasil penelitian menunjukan bahwa dari total 177 responden dengan kategori KEK terbanyak pada pendidikan SD yaitu 7 orang $(43,8 \%)$ dan terendah atau tidak terdapat KEK pada responden yang tidak sekolah $(0 \%)$ dan perguruan tinggi (0\%). Penelitian sebelumnya oleh Pomalingo,dkk (2017) di Kecamatan Tilango Kabupaten Gorontalo mendapatkan hasil bahwa proporsi penderita KEK terbanyak pada tingkat pendidikan SD (50\%). Faktor pendidikan mempengaruhi pola makan ibu hamil, tingkat pendidikan yang lebih tinggi diharapkan pengetahuan atau informasi tentang gizi yang dimiliki lebih baik sehingga bisa memenuhi asupan gizinya. Pemilihan makanan dan kebiasaan diet dipengaruhi oleh pengetahuan, sikap terhadap makanan dan praktek/perilaku pengetahuan tentang gizi melandasi pemilihan makanan. Pendidikan formal dari ibu rumah tangga sering kali mempunyai asosiasi yang positif dengan pengembangan pola konsumsi makanan dalam keluarga (Djamilah, 2008). Hasil penelitian oleh Handayani dan Suci di Wilayah Puskesmas Wedi Klaten (2011) yang menyatakan bahwa ada pengaruh antara pendidikan dengan kejadian KEK. Pendidikan adalah upaya untuk memberikan pengetahuan sehingga terjadi perubahan perilaku positif yang meningkat (Notoatmodjo, 2003).

Dari total 177 responden dengan kategori KEK terbanyak pada Ibu Rumah Tangga yaitu 10 orang $(62,5 \%)$ dan terendah atau tidak terdapat KEK pada responden dengan pekerjaan sebagai petani $(0 \%)$. Wanita yang berperan sebagai ibu rumah tangga dalam hidupnya memiliki tingkat kesehatan yang lebih rendah daripada wanita yang memiliki pekerjaan serta rutinitas di luar 
rumah selain berperan sebagai ibu rumah tangga disamping mengurusi rumah tangga dan anak seperti wanita karir dan pekerja swasta aktif, kemudian diikuti oleh wanita yang berperan sebagai orangtua tunggal dan yang terakhir adalah mereka yang tidak memiliki anak atau tetap melajang (Darmojo, 1998 dalam Najoan dkk, 2011). Penelitian mengenai hubungan tingkat sosial ekonomi dengan kurang energi kronis ( KEK ) pada ibu hamil di Kecamatan Sedayu Kabupaten Bantul pada bulan Maret-Mei tahun 2014 mendapatkan hasil bahwa tidak terdapat hubungan antara tingkat sosial ekonomi seperti pendidikan, pekerjaan, pengetahuan ibu dengan risiko KEK pada ibu hamil. Namun, terdapat hubungan yang bermakna antara pendapatan keluarga dengan ibu hamil dengan risiko KEK dan tidak KEK (Indriany dkk, 2014).

Hasil penelitian menunjukkan dari total 177 responden dengan kategori KEK keseluruhan terdapat pada wanita usia subur yang sedang tidak hamil yaitu 16 orang $(100 \%)$. Untuk mencegah resiko KEK pada ibu hamil sebelum kehamilan wanita usia subur sudah harus mempunyai gizi yang baik, misalnya dengan LILA tidak kurang dari 23,5 cm. Apabila LILA ibu sebelum hamil kurang dari angka tersebut, sebaiknya kehamilan ditunda sehingga tidak beresiko melahirkan BBLR (Kristiyanasari, 2010). Sebagaimana disebutkan di atas, berat bayi yang dilahirkan dapat dipengaruhi oleh status gizi ibu baik sebelum hamil maupun saat hamil. Status gizi ibu sebelum hamil juga cukup berperan dalam pencapaian gizi ibu saat hamil. Status gizi ibu sebelum hamil mempunyai pengaruh yang bermakna terhadap kejadian BBLR. Ibu dengan status gizi yang kurang sebelum hamil mempunyai resiko 4,27 kali untuk melahirkan bayi BBLR dibandingkan dengan ibu yang mempunyai status gizi baik (normal) (Kristiyanasari, 2010).

\section{PENUTUP}

Proporsi penderita KEK terbanyak pada kelompok umur 15-24 tahun, tingkat pendidikan tamatan $\mathrm{SD}$, pekerjaan sebagai ibu rumah tangga dan keseluruhan terdapat pada wanita usia subur dengan status tidak hamil. Disarankan untuk mengurangi risiko KEK pada wanita usia subur perlu peningkatan akses informasi melalui kegiatan KIE terutama pada WUS dengan tingkat pendidikan rendah, memperhatikan beban pekerjaan agar tidak berlebih dan perbaikan gizi pada kelompok remaja dan dewasa awal. Perlu penelitian lanjutan untuk menganalisis faktor yang berpengaruh terhadap kejadian KEK.

\section{DAFTAR PUSTAKA}

Djamilah A. 2008. Faktor Factor yang Berhubungan dengan Kekurangan Energy Kronik di puskesmas jembatan serong Depok. FKM UI. Jakarta.

Handayani S dan Suci B. 2011. Analisis Faktor yang Mempengaruhi Kekurangan Energi Kronis pada Ibu Hamil di wilayah Puskesmas Klaten. Involusi, Jurnal Imu Kebidanan. 1(1).

Helena. 2013. Gambaran Pengetahuan Gizi Ibu Hamil Trimester Pertama dan Pola Makan dalam Pemenuhan Gizi. http://www.repository.usu.ac.id. [diakses 10 Desember 2017].

Indriany. 2014. Hubungan antara Tingkat Sosial Ekonomi dengan Kekurangan Energi Kronis pada Ibu Hamil Di Kecamatan Sedayu Kabupaten Bantul Provinsi Yogyakarta. [Tesis]. Universitas Gadja Mada. Yogyakarta.

Kemenkes RI. 2013. Riset Kesehatan Dasar (Riskesdas 2013). Kemenkes RI. Jakarta.

Kristiyanasari W. 2010. Gizi Ibu Hamil. Nuha Medika. Yogyakarta.

Mboi N. 2013. Gizi Seimbang atasi Masalah Gizi Ganda. Departemen Kesehatan Republik Indonesia. http://www.depkes.go.id/article/view/2239/giziseimbang-atasi-masalah-gizi-ganda.html. 
Najoan. 2011. Hubungan Tingkat Sosial Ekonomi Dengan Kurang Energi Kronik Pada Ibu Hamil di Kelurahan Kombos Barat. [Laporan Penelitian]. Universitas Sam Ratulangi. Manado.

Notoatmodjo. 2003. Kesehatan Masyarakat Ilmu dan Seni. Rineka Cipta: Jakarta.

Pomalingo A, Misnati, Setiawan DI. 2017. Karakteristik Ibu Hamil Kurang Energi Kronik (KEK) di Kecamatan Tilango Kabupaten Gorontalo. Health and Nutritions Journal. 4(1).

Supariasa ID, Bachyar B dan Fajar I. 2013. Penilaian Status Gizi. EGC. Jakarta. Waryono. 2009. Gizi Reproduksi. Pustaka Rihama. Yogyakarta.

Wuryani. 2007. Aspek Kesehatan dan Gizi. Yayasan Obor Indonesia. Jakarta. 